\title{
Obituaries
}

\author{
Editor: Henry R. Rollin
}

Ramon Francis Norris, Consnltant Psychiatrist, Highcroft Hospital, Birmingham

Ramon Norris died after a brief illness on 10 December 1992.

Ray was educated at Handsworth Grammar School and went on to graduate MB ChB at Birmingham University Medical School in 1958. After house jobs at Dudley Road Hospital he undertook his National Service in the Medical Branch of the RAF, seeing active service in Aden. Upon leaving the forces he quickly decided on a career in psychiatry which he found both intellectually stimulating and challenging. He obtained the DPM (Birm) in 1966 and was elected MRCPsych in 1971.

He gave much time to sitting on various committees and was Chairman of the Division of Psychiatry for two years.

During his latter years, he chose mainly to work directly with patients and their general practitioners. He felt that those who must live with the newly evolving services should be allowed the opportunity to develop them as they saw fit.

His approach was one of kindly authority and charming humour which never failed to impress alike his patients and colleagues.

Unfortunately, his expected early death from a myocardial infarct precluded the retirement he was beginning to look forward to and plan for.

$\mathrm{He}$ is survived by his sister Irene.

R. A. W ALL

\section{Christopher OUNSTEd, formerly Consultant Psychiatrist and Director of The Human Development Research Unit at the Park Hospital for Children, Oxford}

In 1957 Kit Ounsted launched the Park Hospital as a "place for children to be well in" in the former neurosis unit of the Warneford Hospital, a house that once belonged to the Bishop. History has it that it was intended to be a shared facility but Ounsted, with prescience that matched his wisdom and verve, introduced a group of tiresome children who immediately effected a purge of the adult incumbents. The group of over a thousand children with epilepsy that he had then assembled for his DM thesis became the source of his many seminal papers on childhood epilepsy. His technique was so fine as to allow him to write (with Janet Lindsay) his last follow-up of a sub-group of 100 children with temporal lobe epilepsy 40 years later without the outcome of a single case being unknown.

He called his interest "Developmental Medicine", a "science of biographies". It accorded with his deviationism in referring to himself as a physician. He believed that he was only doing what all physicians do which was to understand their patients enough to be able to ease their sickness. It described the range of his writings from On Fetal Growth Rate written with his wife Margaret, to studies of the breakdown of parenting in the form of abuse; it afforded the most elegant euphemism yet devised for working with the mentally handicapped. It was a clear statement of policy that the concerns of psychiatrist working with children should be very broad.

His teaching was at its best in the convention of the Oxford tutorial. He would not necessarily be as well informed as his tutee of the matter in hand yet it would be they who would emerge, from minutes to hours later feeling more conversant with the meaning of their own data, or better equipped to pursue a line of thought or therapy. He organised, for two years, a startling two weeks course in developmental medicine for the medical students in which he called upon distinguished colleagues from all over the country to provide first-hand accounts of their work. There remains a select band who remember with affection the camaraderie and the interest of those courses which sadly fell into the maw of the greater good, much to Ounsted's distress.

Although infinitely patient with the individuals who looked to him, he was not clubbable and resisted those aspects of his work that would require participation in large groups. This prevented his science and teaching from having a broader impact, but he strongly encouraged others to travel widely in the dissemination of their knowledge and reminded them that that was the original nature of universities.

He was an early promoter of the work of Henry Kempe on child battering. Kempe, who had lived briefly as a child refugee in Oxford, visited Ounsted. There grew up at once a warm relationship based upon mutual and deep understanding of the complexities of this aspect of human behaviour. Ounsted engaged in clinical work and researched the process and pathways of abuse through the work of excellent and devoted staff. The hospital became known as a centre where difficult issues of abuse 
could receive sensitive treatment and analysis and many cases were referred. Being the fulcrum of this effort was a great burden to him. He could see how doctors could be sucked in to the process of wrongdoing by an effort to care, but then become besmirched by it.

His post retirement years were spent, as indeed most of his life was spent, in Oxford. He went there originally from Christ's Hospital as a War Memorial scholar to University College. Then, after training in paediatrics and being influenced by Donald Court, he served in the RAF but returned to be the registrar, and the life-long friend, of Victoria Smallpiece. Later he became her research assistant in paediatric neurology and thus entered his first phase of productivity. A failure by the MRC to take over this project, as had seemed intended, after seven years of effort, deeply wounded him and imperilled his career. $\mathrm{He}$ and his family relied heavily on his working wife and she provided, then as subsequently, her loyal personal and professional support. Ian Skottowe realised his assets and he re-trained in psychiatry to become the only child and adolescent psychiatrist in the whole region to be based in a hospital; a hospital to which he brought international renown.

The death of his wife in 1988 broke an attachment which was of enormous personal and professional importance to him. They had had four children, two of whom became physicians, all of whom delighted him and informed his work.

DAVID C. TAYLOR

\section{GiUSEPPE PAMPIGLIONE, formerly Head of the Department of Neurophysiology, Hospital for Sick Children, Great Ormond Street, London}

After an eventful time as a medical student in Rome during which he edited an antifascist paper, organised students' demonstrations and managed to get himself arrested by the secret fascist police, Guiseppe Pampiglione qualified with a "summa cum laude" degree in 1942. By then, Pep, as he came to be known, had already decided to devote himself to neurology and neurophysiology and by 1948 had passed his postgraduate examinations in both subjects. Soon afterwards he obtained a travelling scholarship to study cerebral tumours in Paris where he also worked in the EEG Department at the Hospital of St Anne's. Later that year a British Council scholarship took him to the National Hospital, Queen Square.

Pep soon realised that the opportunities in this country were much greater than in post-war Italy and his considerable ability was quickly recognised. He became senior registrar in the EEG department of the National Hospital and later lecturer in clinical neurophysiology in the Institute of Psychiatry. Here, he worked on temporal lobe epilepsy in close association with Murray Falconer and actually took EEG recording from the surface of the brain at operation thus helping to localise the lesion.

The late Sir Charles Symonds, who had befriended him and was most anxious to keep him in this country, advised him to obtain a British qualification and helped him to enter Guy's Medical School as an undergraduate.

A ludicrous situation arose whereby Pep was awarded the MRCP on published work before he had passed his qualifying examinations. At Guy's he taught neurology/neurophysiology to his fellow undergraduate students and in 1956 he was appointed Head of the Department of Neurophysiology at the Hospital for Sick Children, Great Ormond Street before he had actually completed his pre-registration jobs!

For a while Pep combined the above post with that of a consultant psychiatrist at the Royal Free and also for a time at Charing Cross Hospital, but it was his work at Great Ormond Street which was to make his international reputation.

Pep proceeded to the FRCP in 1969 and served as president of the Comparative Medicine Section at the RSM on two occasions. He was also president of the EEG Society and lectured widely both nationally and internationally. He was a visiting professor in the United States, in Germany, in Italy and in China and was elected vice president of the International Federation of EEG and Clinical Neurophysiology and member of the Association of British Neurologists. He was a founder member of the Association of British Clinical Neurophysiologists (for a while served as its president) and of the Biological Engineering Society. He was an honorary member of practically all EEG and Neurophysiological Societies and was on the editorial committees of many learned journals.

Pep had the highest standards for himself which he projected on those around him. Some did not find him an easy colleague for he could be stubborn and argumentative in committees and others sometimes thought him a hard task-master but all respected him for the care and devotion he gave to his department and to his young patients as well as for his honesty and his integrity. He had wide interests, was a good host and a stimulating companion.

He leaves a wife, a daughter and two sons, the eldest of whom is a consultant obstetrician and gynaecologist.

Silvio BeNAIM

Humphrey Richardson, Consultant Psychiatrist, The Royal Victoria Infirmary, Newcastle upon Tyne

Dr Humphrey Richardson died on his 69th birthday on 14 December 1992 following a lengthy and stoic struggle with complications of diabetes. 